\title{
COVID-19 OUTBREAK, TIMBER PRODUCTION, AND LIVELIHOODS IN NEPAL
}

\author{
Bijendra Basnyat ${ }^{* 1,2}$, Sony Baral ${ }^{3}$, Krishna Raj Tiwari' ${ }^{2}$ Gajendra \\ Kumar Shrestha ${ }^{4}$, Bikash Adhikari², Yajna Nath Dahal \\ ${ }^{1,2}$ Biodiversity Finance Initiative - Nepal, United Nations Development Programme, Nepal \\ ${ }^{2}$ Institute of Forestry, Tribhuvan University, Nepal \\ ${ }^{3}$ Resource Nepal, Kathmandu \\ ${ }^{4}$ Sub-Division Forest Office, Ministry of Industry, Tourism, Forest and Environment, \\ Sub-Division Forest Office, Dhankuta, Province 1, Nepal, Province 1, Nepal \\ ${ }^{5}$ Ministry of Forests and Environment, Kathmandu, Nepal \\ *Corresponding author: bbasnyat@yahoo.com
}

\begin{abstract}
The study assesses the likely consequences of COVID-19 in the forest sector of Nepal, focusing on timber production and rural livelihoods. The study conducted telephone interviews along with a review of the secondary source of information and consultations. The timber production in 2020 is likely to decrease by $80 \%$ compared to previous years, resulting in a monetary loss of NRs 647.0 million. Furthermore, local community will lose 147,447 days of employment, amounting NRs 117.9 million. This will make livelihoods of the people more vulnerable. Returning of youths from abroad can further escalate biodiversity threats. Timber import is likely to increase in the country, thus impacting on local level employment opportunities. Both long-term and short-term strategies are necessary to revive the timber production and rural livelihoods, where priority should be on increasing investment in the forestry sector. However, public-sector investment is declining. Hence there is a need to expand conservation finance portfolios to incentivise rural people on timber production and achieve synergies between conservation and livelihood outcomes.
\end{abstract}

Keywords: Timber - employment - timber import - livelihoods - conservation consequences 


\section{INTRODUCTION}

In Nepal, forests cover $44.7 \%$ of the landmass of the country, of which more than one third of the forests (2.39 million ha) are handed over to the local communities for its protection, management and sustainable use benefitting 2.9 million households (MoF 2020a). Timber are produced from the three main sources in the country, which include (a) government managed forests including collaborative forests (b) community forests and (c) private land, including trees on farmland and private forests (MoF 2020a). Of the total timber produced in the country, private land supplies nearly nine tenth $(86.6 \%)$ of the timber volume produced in the country followed by the government managed forests $(7.7 \%)$ and community forests (5.5\%). According to the Economic survey of the fiscal year (2019/2020), forests produced 10.2 million cubic feet of timber and generated government royalty of NRs 279.9 million. In addition, timber is also the main source of income of the rural communities, which contributed to more than half of the total forest income(Meilby et al. 2014). Rural communities are using income on forest management and community development, which had diversified the rural livelihoods (Lund et al. 2014, Baral et al. 2019). However, social safety nets are weak in the developing countries, which often leads to increased unemployment, poverty and food insecurity in the crisis (FAO 2020).

Corona Virus Disease (COVID-19) pandemic has hit all sectors of economy, where the impact would be quite immense in the agriculture, industry, tourism, and remittance (ADB 2020). Furthermore, the condition is becoming worse day by day and posing enormous health, economic, environmental, and social challenges (Chakraborty and Maiti 2020). Restrictions on physical activities had impacted forestry activities, especially on timber production and supply chain, which had put the livelihoods and forest-based industries at risk (FAO 2020). The strict lockdown period of the country (March- June) coincides with the peak timber harvesting season of the country (between February to July). According to the Forest legislation of the country (Forest Rule, 1996), the timber can only be harvested between mid-October to mid-June. Surprisingly, the government did not consider this reality. Consequently, forestry sector has not been recognized as the essential service sector, thus resulting in many restrictions during the lockdown, especially on the movement, harvesting, logging, and transportation. This is because of two obvious reasons. First, the forest sector is seen as more resilient because harvesting cycles are longer 
compared to other commodities. Secondly, the sector has a very nominal contribution to the national economy (less than $1 \%$ on the total revenue received by the government in 2019 (MoF 2020 a).But its contribution in subsistence economy is largely ignored that accounts for a sizable share of national income, which ranges between $3.0-11.3 \%$ of total household income (Meilby et al. 2014).

The effect of the current COVID-19 pandemic on the forestry sector has not been explored, especially focusing on the timber production and its consequences on the rural livelihoods. This issue become more important when forest products remain important to most households in Nepal in (Meilby et al. 2014).On the contrary, recent literature highlighted the positive side of the COVID-19 or lockdown, such as strict quarantine benefits environment (Wang and $\mathrm{Su} 2020$ ) or ecosystems are being greatly recovered (Chakraborty and Maiti 2020). Can we sustain these impacts in the long run? What are the consequences to the national economy and to the people who depend on ecosystem goods and services? Hence, this paper explores the impact of COVID-19 focusing on timber production and suggested measures to cope with the current crisis.

\section{MATERIALS AND METHODS}

The study relied on the qualitative methods for an in-depth study of real-world problems from the perspective of participants (Yin 2014). The methods comprise the desk review, telephone interview, and interactions.

The study reviewed research papers and grey literature (newspaper articles and blogs) to understand consequences of the COVID-19 pandemic. The study reviewed the timber production and import statistics, forestry legislations, economic survey, and Government of Nepal budget speeches and program to understand how current policy provision will influence on the COVID-19 recovery plan of the forestry sector.

The study was conceptualized in the lockdown period. Face to face interview was not possible. Hence, telephonic interview method was followed. This enabled us to interact freely in a limited period and very costeffective. Furthermore, this method was proved to be effective in collecting information when interviewers clearly understand subject (Musselwhite et al. 2007). The study identified three categories of the respondents, which include (a) forest officials working within the aegis of the Ministry of Forests and Environment at the national and sub-national levels (b) forest 
user groups leaders such as chair, vice chair, secretary and treasurer and (c) timber entrepreneurs, such as sawmill operators, timber contractors and collectors. The interviews focused on (a) what are major consequences of the COVID-19 (b) How the current crisis had affected the livelihoods of the forest-dependent people and (c) What could be done to cope with and mitigate the current crisis in the sector?

The study followed a purposive sampling method and also relied on the existing network to collect information. The study identified the list of the persons whose telephone number were available and called them randomly. A total of 82 respondents were selected purposely comprising of 33 forest officials working; 20 forest users groups' leader; and 24 timber entrepreneurs. The response rate was nearly $80 \%$.Each interview lasted for12-15 minutes. The study purpose was explained to respondents, and consent was obtained. Respondents were scattered throughout the country, representing all the physiographic regions and the provinces. The study did not encounter any noticeable problems during the interview because of a long-term working relationship with the respondents and had mutual trust in each other. Likewise, none of the participants left the interview in the middle. But still, the study could not meet the target because some were not reachable due to changes in their contact number. Likewise, some were unaware of the present situation since they were currently out of their duty station/villages or shifted to other work.

We conducted the interview with the respondents, till we got a new information on the COVID consequences. Besides, authors also participated in dozens of recent webinars to understand expert opinions on consequences and way forward. Data were analysed qualitatively and shared with selected senior government officials, forest entrepreneurs, and researchers using online platforms. While most of the respondents confirmed with the study findings, few further provided explanations and additional information.

\section{RESULTS}

\section{Perception on COVID-19 Consequences}

The respondents reported that the COVID-19 has both positive and negative consequences (see table 1). The positive includes lesser disturbance to the wildlife habitat, low carbon emission, and pollution and increased observation or sighting of the wildlife. However, these positive consequences are short term in nature and for the time being only. It will 
vanish once the lockdown is lifted or even ease down. A government official said, Are you crazy? How can a devil bring a positive impact? I hardly recall any positive impacts. Whatever positive impacts others are claiming, have they analysed the consequences of it from the human well-being, and conservation perspectives. The footprints of these shortterm benefits will have adverse consequences on both the forests and the peoples' livelihoods in the coming days. Have you observed that hunting and poaching have increased? People are jobless, and trees are lying inside the forest. As evident from Table 2, the main consequences would be a decrease in revenue or income, followed bya lower quantity of the forest product harvest and loss of income and employment opportunities. Other consequences include pleasure hunting and investment-related risks of the forest entrepreneurs.

Table 1: Consequences of the COVID-19

\begin{tabular}{|c|c|c|c|c|}
\hline \multicolumn{5}{|c|}{ Unit: \% of respondents } \\
\hline Consequences & $\begin{array}{c}\text { Forest } \\
\text { officials } \\
(n=33)\end{array}$ & $\begin{array}{c}\text { Forest user } \\
\text { groups' } \\
\text { leaders } \\
(\mathbf{n}=\mathbf{2 0})\end{array}$ & $\begin{array}{c}\text { Forest } \\
\text { entrepreneurs } \\
(n=24)\end{array}$ & $\begin{array}{c}\text { Overall } \\
(n=77)\end{array}$ \\
\hline \multicolumn{5}{|c|}{\begin{tabular}{|c|c|c|} 
Positive consequences \\
\end{tabular}} \\
\hline $\begin{array}{l}\text { Less disturbance to wildlife } \\
\text { habitat }\end{array}$ & 6.1 & 20.0 & 12.5 & 11.7 \\
\hline Low carbon or pollution & 6.1 & 5.0 & 8.3 & 6.5 \\
\hline $\begin{array}{l}\text { Wildlife observation } \\
\text { increased }\end{array}$ & 12.1 & 20.0 & 8.3 & 13.0 \\
\hline \multicolumn{5}{|c|}{ Negative consequences } \\
\hline Decrease royalty/ revenue & 84.8 & 90.0 & 83.3 & 85.7 \\
\hline $\begin{array}{l}\text { Low quantity and quality } \\
\text { of forest products harvest }\end{array}$ & 75.8 & 75.0 & 62.5 & 71.4 \\
\hline $\begin{array}{l}\text { Loss of income and } \\
\text { employment }\end{array}$ & 60.6 & 70.0 & 83.3 & 70.1 \\
\hline Pleasure hunting/ Poaching & 60.6 & 90.0 & 50.0 & 64.9 \\
\hline $\begin{array}{l}\text { Investment related risk/ } \\
\text { uncertainty }\end{array}$ & 15.2 & 40.0 & 83.3 & 42.9 \\
\hline $\begin{array}{l}\text { Poor implementation } \\
\text { of forest management } \\
\text { practices }\end{array}$ & 24.2 & 60.0 & 50.0 & 41.6 \\
\hline $\begin{array}{l}\text { Increase dependency on } \\
\text { firewood }\end{array}$ & 21.2 & 60.0 & 16.7 & 29.9 \\
\hline Illicit felling/hunting & 24.2 & 25.0 & 20.8 & 23.4 \\
\hline
\end{tabular}




\section{Timber Harvest Volume}

During the interaction, majority of the respondents perceived that only $15-20 \%$ of total timber production potential in their locality is harvested; harvesting permits are issued for 30-40\%, and processes are yet to be initiated for the rest (40-55\%). Almost all respondents mentioned that timber production would decrease by $60 \%$ to $80 \%$ compared to the previous year. Furthermore, forest officials cannot issue harvesting permits or initiate harvesting after the mid of June according to the present forestry legislation (Forest Regulation, 1995 rule (16). Thus, a timber production would likely to decrease in the country, A forest official said, "I am not even in the position of issuing the harvesting permit anymore. I am yet to monitor the harvested plots. I have very limited human resources. My priority will be to monitor those plots rather than issuing the new harvesting permits. My job will be in danger if the forests are over-harvested. Why should I take a risk?

Timber entrepreneurs and forest user group leaders mentioned that harvesting would be around $20-30 \%$ of the last year's timber harvest. Though the timber harvesting season officially starts from mid-October in Nepal, most of the forest user groups approached the concerned forest offices lately, i.e., mostly during the second week of January. This is a very common practice because of the peak farming period (paddy harvesting and wheat cultivation)and the festival seasons. While most of the forest user groups are yet to initiate harvesting or receive harvesting permits, the government issued a circular on 28 May 2020 imposing restriction on harvesting of the timber. While the main justification was to combat the illegal harvesting of the timber, this situation has further decreased the volume of timber production in the country. As a forest user group leader said, we never know COVID-19 will be pandemic, and we will be under lockdown. Now we cannot even harvest a single tree this year because of the government recent circulars. We get a good lesson this year; never wait till the last moment. Guided by the above, the study estimated the likely volume of timber production in 2020 (Table 2). There will be a sharp decline in timber production compared to the previous year. 
Table 2: Timber production in 2018/2019 and estimated timber production in 2020

\begin{tabular}{|c|c|c|c|}
\hline Item & Unit & 2018/2019" & $2020^{* * *}$ \\
\hline \multicolumn{4}{|l|}{ 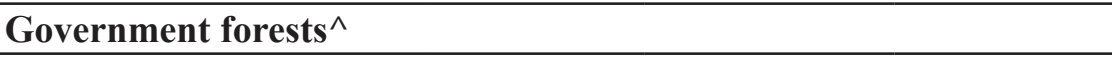 } \\
\hline Timber production ${ }^{\wedge}$ & Cubic feet & $560,250.9$ & $112,050.2$ \\
\hline Firewood production & Chatta & $79,532.6$ & $15,906.5$ \\
\hline \multicolumn{4}{|c|}{ Private land (Private forests and trees on farmland) } \\
\hline Timber production & Cubic feet & $6,338,242.6$ & $3,802,945.5$ \\
\hline \multicolumn{4}{|l|}{ Community forests } \\
\hline $\begin{array}{l}\text { Timber sale from } \\
\text { community forests }\end{array}$ & Cubic feet & $422,727.3$ & $84,545.5$ \\
\hline $\begin{array}{l}\text { Firewood sale from } \\
\text { community forests }\end{array}$ & Chatta & 394.6 & 78.9 \\
\hline
\end{tabular}

Source: "DoF 2018; "* Estimated based interaction with the respondents;

Note: ^ This figure does not include the total timber production volume of the community and collaborative forests(Divisional Forest Office records)

The study estimated that timber production from the government forests would be $112,050.2 \mathrm{cft}$ which is only $20 \%$ of the total volume of the timber produced in last year volume. This is mainly because the government issued a circular on 28 May 2020 restricting the timber harvesting from the government forest in light of the current COVID-pandemic (MoEF, 2020). The private land, especially on tree on farmland, homestead and private forests are becoming an important source of the low value timber in the country and supply to the forest-based industries, such as plywood industry and for construction purposes. The study estimated that timber from the private land would decrease by $60 \%$ of timber volume compared to the last year. Likewise, forest user groups sale of timber and firewood outside the group would decrease by almost $80 \%$ compared to last year.

\section{Monetary Loss}

Monetary loss from timber will occur at three levels. The government loses royalty, forest user groups lose their income from the sale of timber and firewood, and timber entrepreneurs will lose money who have already made pre-investment to support forest user groups for harvesting and logging operations. The total monetary loss at three levels 
has been estimated NRs 647.0 million (see table 3), where government royalty loss of NRs 300.5 million excluding the income and royalty of timber from private land. This study does not estimate for the private land with the assumption that trees can be harvested once the lockdown is lifted. Respondents argued that timber trade from community forests will decrease by $70-90 \%$ compared to the previous year. Consequently, forest user groups will lose NRs 273.1 million. Generally, timber entrepreneurs were making pre-investment of NRs 217.2/per cft for supporting harvesting and logging operations. However, most of the timber entrepreneurs saw a bleak chance of getting back their return. They reported that they could hardly recover $10-30 \%$ of their pre-investment. If they would be only able to recover $20 \%$ of their pre-investment, their investment risk is NRs 73.4 million. This is mainly because they had already provided financial support to the forest user groups and other people in the value chain. This will also impact on the livelihoods of the people, who are dependent on forest resources in general and timber economy in particular.

Table 3: Estimated timber revenue/incomeloss

Unit: NRs million

\begin{tabular}{|c|c|c|c|c|}
\hline Item & 2018/2019" & $\begin{array}{l}\text { Estimated } \\
(2020)\end{array}$ & Loss & Remark /Assumption \\
\hline $\begin{array}{l}\text { Government } \\
\text { royalty }\end{array}$ & 375.7 & 75.1 & 300.5 & $\begin{array}{l}\text { The government royalty } \\
\text { will decrease by } 80 \% \\
\text { compared to the previous } \\
\text { year }\end{array}$ \\
\hline $\begin{array}{l}\text { Forest user } \\
\text { group income }\end{array}$ & 341.3 & 68.3 & 273.1 & $\begin{array}{l}\text { Users can trade only } 20 \% \\
\text { of timber in the market } \\
\text { compared to previous year }\end{array}$ \\
\hline $\begin{array}{l}\text { Entrepreneur } \\
\text { investment risk }\end{array}$ & 0 & 128.1 & 73.4 & $\begin{array}{l}\text { Invested NRs } 217.2 / \mathrm{cft} \text { to } \\
\text { access timber }\end{array}$ \\
\hline Total & & & 647.0 & \\
\hline
\end{tabular}

Source: "DoF2018; **amount is calculated based on the sale quantity of timber and firewood mentioned in table 3 multiplied by NRs 800/cft and NRs 8000/chatta respectively 


\section{Rural livelihoods}

COVID-19 hasalso impactedin the current year government expenditure as well as next year's program. In March 2020, the Ministry of Finance issued circular suspending the fund allocated for capital expenditure and instructed not to initiate new interventions. The forest officials suspended all forest conservation and community infrastructure construction work, which has the potential to generate local employment. A forest officer said, "We have view tower construction and plantation program which will generate employment of 200 days. However, we cannot implement it though we have completed preparatory work. When there is no employment in the other sector, we should work to create employment opportunities. Government officials estimated around 30\% of their development budget will getfreeze this year. Furthermore, the forestry sector budget has declined by $9.1 \%$, i.e., from NRs 13,830 million in $2019 / 20$ to $12,785.3$ million in $2020 / 21$, where the sharp fall is observed on capital expenditure, by $23.3 \%$ (MoF 2020a). This will affect both forest conservation as well as livelihoods.

Timberharvesting generates employment opportunities. Interactions with timber entrepreneurs,including a review of government norms, reveal that the local community will generate income of NRs $150.8 / \mathrm{cft}$ of timber as a wage while working on tree marking, felling, piling, logging, and storage operations. As timber harvesting quantity has decreased by $786,382.6 \mathrm{cft}$ this year, the local community will lose NRs 117.9 million, equivalent to 147,447 days of wage during this harvesting period (January-June).

Forest user groups are using their income to implement forest management, rural development, and livelihood improvement programs and creating a paid employment of two to four days per household. However, they could hardly afford to implement such a program this year. A chairperson of forest user group said, every household gets a paid employment of two days during the timber harvesting operations and also about two days in community development work. However, we would hardly provide such benefits this year. Income from forest user groups would decrease drastically, which will impact the life of the people. According to the Community Forest Guideline 2014, forest user groups should spend at least one-fourth of income on pro-poor programs. However, many forest user groups reported that they would face challenges even on bearing forest management costs, especially on deploying the forest watchers and paying 
their salary. A CF leader said, "I would have no income from my forests. How can I support my poor members who need livelihood protection or relief support at the current pandemic? It indicates that there will be no income-generating activities.

During the COVID-19 pandemic, the country is passing through the lockdown, and no economic opportunities exist in the cities or urban centers. Consequently, people return to their villages, and a reverse trend of migration happens (from urban to rural). A CF leader said, around $80 \%$ of the members have returned to the villages during the lockdown period, of which most are youth. Many youths who hardly spend a few days in the villages have a lot of leisure time and often collude with others for"pleasure hunting." Almost all forest officials perceived that threats to wildlife have increased during the lockdown. There were more than a dozen of the media reporting on illegal wildlife hunting, however much more incidences are unnoticed. A forest official said, "I have registered three wildlife-related crimes in my duty station within a two-week period, of which none have featured in media."Moreover, the lockdown provided a favorable environment for the poachers and hunters since the priority of the security forces has shifted on minimizing COVID-19 outbreaks. A CF leader said we have now observed the pleasure hunting. This may become a livelihood strategy for the youths in the absence of economic activities. COVID-19 pandemic has further increased firewood dependency. In rural areas, people were using LPG gas for cooking food. However, the supply system is affected either by lockdown or limited cash flow in the family. Consequently, villagers are shifting on firewood. ACF leader said, "Before the Corona, very few families were using firewood. About $67 \%$ of the families use firewood now. If this situation continues for another next month, I can bet that everyone will use firewood. How can we save our forests with an empty stomach?"

\section{Future Priority}

Majority of respondents (see table 4) suggests for amending/relaxing current timber harvesting rule, especially on allowing of accumulated harvesting of this year in the subsequent year; followed by implementing quick impact livelihoods interventions and impose taxes on timber imports to safeguard the national timber and forest-based industries. In the long run, the government should give priority in implementing programs having potentiality to generate local level employment opportunities while 
expanding conservation finance portfolio, especially for generating fund to incentivize conservation.

Table 4: Priority strategy to cope with the current crisis

Unit: \% of respondents

\begin{tabular}{|c|c|c|c|c|}
\hline Priority strategy & $\begin{array}{c}\text { Forest } \\
\text { officials } \\
(n=33)\end{array}$ & $\begin{array}{l}\text { Forest User } \\
\text { groups } \\
\text { leaders } \\
(\mathbf{n}=\mathbf{2 0})\end{array}$ & $\begin{array}{c}\text { Forest } \\
\text { entrepreneurs } \\
(n=24)\end{array}$ & $\begin{array}{c}\text { Overall } \\
(n=77)\end{array}$ \\
\hline \multicolumn{5}{|c|}{ Immediate intervention } \\
\hline $\begin{array}{l}\text { Amend harvesting rule, } \\
\text { especially allowing } \\
\text { accumulated quantity in } \\
\text { next year }\end{array}$ & 60.6 & 60.0 & 83.3 & 67.5 \\
\hline $\begin{array}{l}\text { Implement quick impact } \\
\text { livelihood interventions/ } \\
\text { income generating } \\
\text { activities }\end{array}$ & 45.5 & 75.0 & 25.0 & 46.8 \\
\hline $\begin{array}{l}\text { Impose import taxes } \\
\text { on timber imports to } \\
\text { safeguard national } \\
\text { production }\end{array}$ & 36.4 & 70.0 & 66.7 & 54.5 \\
\hline Increase budget/finance & 36.4 & 70.0 & 83.3 & 59.7 \\
\hline $\begin{array}{l}\text { Provide incentive/subsidy/ } \\
\text { grants }\end{array}$ & 30.3 & 25.0 & 50.0 & 35.1 \\
\hline \multicolumn{5}{|c|}{ Long term priority } \\
\hline $\begin{array}{l}\text { Promote forest-based } \\
\text { processing enterprises, } \\
\text { including mechanisation } \\
\text { of timber harvesting }\end{array}$ & 63.6 & 30.0 & 29.2 & 44.2 \\
\hline $\begin{array}{l}\text { Strengthen sustainable } \\
\text { forest management } \\
\text { practices }\end{array}$ & 12.1 & 60.0 & 8.3 & 23.4 \\
\hline $\begin{array}{l}\text { Provide soft/subsidised } \\
\text { loan }\end{array}$ & 12.1 & 15.0 & 83.3 & 35.1 \\
\hline $\begin{array}{l}\text { Expand conservation } \\
\text { finance portfolio }\end{array}$ & 36.4 & 40.0 & 33.3 & 36.4 \\
\hline
\end{tabular}

DISCUSSION

Domestic production of timber and government royalty would decrease drastically (Table 3), which is consistent with the recent economic 
survey report of Nepal, which estimated that timber production and forests royalty has decreased by $46 \%$ and $600 \%$, respectively, compared to the previous year (MoF 2020a). In Nepal, timber production is often hindered by imperfect policy, legislative and bureaucratic hurdles, along with high transaction costs(Basnyat et al. 2019, Basnyat et al. 2018). Generally, increment in the forest product volume (timber in our case) is harvested according to the management plan. However, the increment in the timber stock volume cannot be harvested next year if no harvesting is carried out within the current year despite timber is not perishable like agriculture crop. Furthermore, this will impact on the sustainable management forests, since the plan are not implemented according to the prescriptions. As timber would remain in the forests, this will affect both the national treasury as well as the forest users' income. Considering the present crisis, the government should make a policy decision to allow harvesting of increased timber volume of the last year in the preceding year, aiming to boost timber production. Besides, this will generate funds in the current crisis without having adverse consequences.

In Nepal, domestic timber production is not enough to meet the national demand. In 2020, the country imported 0.78 million cft of timber. However, timber import volume has decreased compared to previous year, which was 0.98 million, in 2019(MoF 2020a). This has happened because of the increased in timber production. The timber production was 9.0 million cft in 2018 which reached to 19.4 million $\mathrm{cft}$ in 2019. (MoF 2020b). However, production volume has now decreased to 10.3 million in 2020. Furthermore, the study estimated that timber production in the country would decrease by nearly half because of the imposition of the strict lockdown in the country. It seems that timber import will increase despite the government's priority to reduce import. Hence, challenge remains to increase timber production and safeguard the domestic timber industry. Thus, the government should impose COVID-19 tariff on timber imports, aiming to protect national timber entrepreneurs' investment. This generated fund shall be explicitly utilized in COVID-19 recovery programs in the forestry sector, especially to incentivize forest user groups and timber entrepreneurs. 
People's livelihoods are under threat. While the government expenditure on forestry sector has declined, the forest user groups would struggle to implement forestry and rural development programs. With more than $40 \%$ of the country's land is under the forests, this sector is going to face unprecedented challenges in the future. The unemployment rate in the country will increase, while three out of five people are already out of a job (Koirala 2020).Besides, around 3.5 million people may return from abroad who migrated for foreign employment (Shrestha and Mandal, 2020). Most of them are rural inhabitants. In the absence of other livelihood options in the villages and the increasing unemployment, forests would be the primary potential source of rural livelihoods. The current pandemic has also threatened the existence of wildlife. Furthermore, incidences of wildlife poaching, and hunting, illegal harvesting of the non-timber forest products, and timber are often reported during the lockdown. In reduced flow of financial resources, forest users' groups are not able to (a) sustain watchers or doing regular patrol against the threat of poaching and disturbance of the habitat for collection of herbs as well as forest fires, (b) do regular habitat improvement and forest management activities such as plantation, fire management, cleaning operation (c) construction of the community infrastructures. If forests cannot contribute to people's livelihoods in the current pandemic, generating peoples' participation in forest conservation would be remote in the future. Hence, at the juncture of unprecedented tragic time, the intervention on the forestry sector needs to be implemented, aiming to generate both short-term and long-term income and employment. The forests sector should now think proactively about how to create more forest-based employment in the coming days to reduce direct threats in the forests. Possible options would be to provide incentives and subsidized loans to establish forest-based industries, aiming to create local-level employment, among others. The local and provincial governments should provide incentives to establish a forest-based enterprise.

The timber-based industries in 2014 have invested over NRs 18.2 billion and generated employment to 812,090 sustainable full-time equivalent jobs (Subedi et al. 2014). The study indicates that the investment of forest entrepreneurs is at risk. Likewise, their business turns over will decrease drastically and will even face difficulties in retaining human resources. In the current situation of the pandemic, the government should 
support those industries on accessing the subsidized loans, especially for establishing value-added forestry enterprises, which will not only create employment but also reduce the import. Maintaining the self-sufficiency economy should be the priority and lessons in the current pandemic.

In the post-COVID-19 scenario, forestry will be the less priority of the country since it has not been accounted as a strong pillar of the Nepalese economy. The sector has a very nominal contribution (less than $1 \%$ on the total national revenue(MoF 2020a).Budget allocation from the national treasury is very minimal and even in a declining trend. In the current situation, the priority of the national government, as well as the development partners of Nepal, will naturally shift in the health sector. According to the Ministry of Finance, COVID-19 assistance portal (2020), development partners had expressed financial commitments of US\$ 13.8 million for the recovery from COVID-19 pandemic, of which 6.4 million has been disbursed already (MoF2020c). The assistance largely focused on health sub-sector, women empowerment, and reproductive health. Furthermore, forestry sectors' contribution to the national and local economy would decline because of the limited flow of international visitors in the country impacting conservation area income, limited harvesting of the timber and non-timber forest products, and decrease in the financial assistance from the government and development partners. In this scenario, the Ministry of Forests and Environment and different development partners working in the forest sector should design different innovative biodiversity financing mechanisms to expand conservation finance portfolios. Some of the possible measures could be crowd funding, philanthropic donations, and implementation of the localized payment for ecosystem services, including realigning expenditure.

\section{CONCLUSIONS}

The monetary loss in the timber sector alone is estimated at around NRs 647.09 million. Likewise, the local community loses NRs 147,447 days of employment during this harvesting period (February to June), amounting to NRs 88.9 million. The consequences discussed here are preliminary and it requires a comprehensive assessment covering different sub-sectors within the forestry. Nevertheless, this will be helpful to understand the magnitude of the impacts and devise appropriate mitigation options for developing 
the recovery plan and thereby initiate deliberate discussion among the stakeholders.

Our analysis reveals that timber import in the country likely to increase while rural peoples' livelihoods will be more vulnerable. With the limited budget to finance the forestry program, both the government and community will struggle to finance the sector. Furthermore, the protection and reviving of the forestry sector in the Post COVID-19 situation is urgent. Hence, the study recommends implementing long-term and shortterm strategies to protect the timber business in the country. The short-term strategy could be relaxing the provisions of current timber harvesting, implementing quick livelihoods intervention, imposing COVID-19 tax on timber import, implementing crowd funding, incentivize conservation, and recognizing forestry as the essential services. In the long run, the country should encourage establishing forest-based processing industries to generate sustainable employment. Finally, the Ministry of Forests and Environment should design and implement different finance solutions to diversify the current conservation finance portfolio to achieve synergies between conservation and livelihood outcomes.

\section{ACKNOWLEDGMENTS}

We would like to thank Prof Dr. Ridish Kumar Pokharel, Mr. Suman Bhattaria, Dr. Dipesh Pyakurel, Mr. Ganesh Raj Acharya,Prof Dr Santosh Rayamahji and Dr. Kalyan Gauli, for providing comments and suggestions to improve this manuscript. We are thankful to the peer reviewers for their inputs and time for improving the manuscript. Finally, we would like to thank all the respondents for their time and valuable insights during this difficult period of life.

\section{DISCLAIMER}

The opinions expressed in this publication are those of the authors. They do not purport to reflect the opinions or views of the institutions, which they represent.

\section{REFERENCES}

ADB. (2020). Micro economic update, Nepal. Vol. 8 (1). Asian Development Bank, Nepal Resident Mission. 
Baral, S., Chhetri, B. B. K., Baral, H. \& Vacik, H. (2019). Investments in different taxonomies of goods: What should Nepal's community forest user groups prioritize? Forest policy and economics, 100: 24-32. https://doi:10.1016/j.forpol.2018.11.006.

Basnyat, B. (2020). Commodifying the community forestry: a case from scientific forestry practices in Western Hills of Nepal. Journal of Forest Research, 25(2): 69-75. https://doi.org/10.1080/13416979. 2020.1743406.

Basnyat, B., Treue, T. \& Pokharel, R. K. (2019). Bureaucratic recentralisation of Nepal's community forestry sector. International Forestry Review, 21(4): 401-415. https://doi. org/10.1505/146554819827906861.

Basnyat, B., Treue, T., Pokharel, R. K., Lamsal, L. N. \& Rayamajhi, S. (2018). Legal-sounding bureaucratic re-centralisation of community forestry in Nepal. Forest Policy and Economics, 91: 5-18. https://doi.org/10.1016/j.forpol.2017.08.010.

Chakraborty, I. \& Maity, P. (2020). COVID-19 outbreak: Migration, effects on society, global environment and prevention. Science of The Total Environment, 728: 138-882. https://doi.org/10.1016/j. scitotenv.2020.138882

DoF. (2018). Annual Report, 2017/2018. Nepal. Department of Forest.

FAO. (2020). The impacts of COVID-19 on the forest sector: How to respond?. Food and Agriculture Organizations of the United Nations (FAO). FAO, Italy, Rome. https://doi.org/10.4060/ca8844en

Koirala. K. R. (2020, May 17). Three in every five employees lost their jobs in Nepal due to COVID-19 crisis. My Republica. https:// myrepublica.nagariknetwork.com/news/every-three-in-fiveemployees-lost-their-jobs-in-nepal-due-to-covid-19-crisis/.

Lund, J. F., Baral, K., Bhandari, N. S., Chhetri, B. B. K., Larsen, H. O., Nielsen, Ø. J. \& Treue, T. (2014). Who benefits from taxation of forest products in Nepal's community forests?. Forest Policy and Economics, 38: 119-125. https://doi.org/10.1016/j. forpol.2013.04.010

Meilby, H., Smith-Hall, C., Byg, A., Larsen, H. O., Nielsen, Ø. J., Puri, L. \& Rayamajhi, S. (2014). Are Forest Incomes Sustainable? Firewood and Timber Extraction and Productivity in Community 
Managed Forests in Nepal. World Development, 64: S113-S124. doi:10.1016/j.worlddev.2014.03.011 http://dx.doi.org/10.1016/j. worlddev.2014.03.011

MoF. (2020a). Economic survey: Fiscal year 2019/2020. Ministry of Finance, Nepal https://mof.gov.np/uploads/document/file/ Economic_Survey_2076-77.pdf.

MoF. (2020b). Budget Speech: Fiscal Year 2020/2021. Ministry of Finance, Nepal https://drive.google.com/file/d/1siJj4sviMo9 Scd3iDrW3LjS_10Gv390/view.

MoF. (2020c). Covid-19 Assistance Portal. Ministry of Finance, Nepal. https://amis.mof.gov.np/web/guest/covid-19?p_p_auth= GkJbWqAb\&p_p_id=advancesearch_WAR_AMPportlet\&p_p_ lifecycle $=0 \& p \_p \_s t a t e=$ maximized $\& p \_p \_$mode $=v i e w \& p \_p \_c o l$ $\mathrm{id}=$ column\&p_p_col_count $=1 \&$ _advancesearch_WAR_AMPportlet activityId $=26052 \&$ _advancesearch_WAR_AMPportlet_render= activityDetails.

Musselwhite, K., Cuff, L., McGregor, L. \& King, K. M. (2007). The telephone interview is an effective method of data collection in clinical nursing research: A discussion paper. International Journal of Nursing Studies, 44(6): 1064-1070. https://doi.org/10.1016/j. ijnurstu.2006.05.014

Shrestha, P.M. \& Mandal, C.K. (2020, April 22). With hundreds of thousands of migrants predicted to return home, Nepal needs to brace for a crisis. The Kathmandu Post. https://kathmandupost.com/ national/2020/04/22/with-hundreds-of-thousands-of-migrantspredicted-to-return-home-nepal-needs-to-brace-for-a-crisis.

Subedi, B.P., Ghimire, P.L., Koontz, A., Khanal, S.C., Katwal, P., Sthapit, K.R \& Khadka, S., (2014). Private sector involvement and investment in Nepal's forestry: Status, prospects and ways forward. Study Report, Multi-Stakeholder Forestry Programme-Services Support Unit, Babarmahal, Kathmandu, Nepal.

Wang, Q. \& Su, M. (2020). A preliminary assessment of the impact of COVID-19 on the environment-A case study of China. Science of the Total Environment, 728: 138915. https://doi.org/10.1016/j. scitotenv.2020.138915. 
32 COVID-19 OUTBREAK, TIMBER PRODUCTION, AND LIVELIHOODS IN NEPAL

World Bank. (2020). Nepal Must Ramp Up COVID-19 Action to Protect Its People, Revive Economy. https://www.worldbank.org/en/news/ press-release/2020/04/11/nepal-must-ramp-up-covid-19-action-toprotect-its-people-revive-economy;)

Yin, R.K. (2014). Case study research: Design and methods. Newbury Park. Sage publications. 